\title{
Co-Management of Sewage Sludge and Other Organic Wastes: A Scandinavian Case Study
}

\author{
Clara Fernando-Foncillas ${ }^{1}$, Maria M. Estevez ${ }^{2}$, Hinrich Uellendahl ${ }^{3}$ and Cristiano Varrone ${ }^{1, * \text { (D) }}$ \\ 1 Section for Sustainable Biotechnology, Aalborg University Copenhagen, A.C. Meyers Vænge 15, \\ 2450 Copenhagen, Denmark; cff@bio.aau.dk \\ 2 Aquateam COWI, Karvesvingen 2, 0579 Oslo, Norway; mmes@cowi.com \\ 3 Faculty of Mechanical and Process Engineering and Maritime Technologies, \\ Flensburg University of Applied Sciences, Kanzleistr. 91-93, 24943 Flensburg, Germany; \\ hinrich.uellendahl@hs-flensburg.de \\ * Correspondence: cva@bio.aau.dk
}

Citation: Fernando-Foncillas, C.;

Estevez, M.M.; Uellendahl, H.;

Varrone, C. Co-Management of Sewage Sludge and Other Organic Wastes: A Scandinavian Case Study Energies 2021, 14, 3411. https:// doi.org/10.3390/en14123411

Academic Editor: Luisa Gouveia

Received: 19 May 2021

Accepted: 7 June 2021

Published: 9 June 2021

Publisher's Note: MDPI stays neutral with regard to jurisdictional claims in published maps and institutional affiliations.

Copyright: (c) 2021 by the authors. Licensee MDPI, Basel, Switzerland. This article is an open access article distributed under the terms and conditions of the Creative Commons Attribution (CC BY) license (https:// creativecommons.org/licenses/by/ $4.0 /)$.

\begin{abstract}
Wastewater and sewage sludge contain organic matter that can be valorized through conversion into energy and/or green chemicals. Moreover, resource recovery from these wastes has become the new focus of wastewater management, to develop more sustainable processes in a circular economy approach. The aim of this review was to analyze current sewage sludge management systems in Scandinavia with respect to resource recovery, in combination with other organic wastes. As anaerobic digestion (AD) was found to be the common sludge treatment approach in Scandinavia, different available organic municipal and industrial wastes were identified and compared, to evaluate the potential for expanding the resource recovery by anaerobic co-digestion. Additionally, a full-scale case study of co-digestion, as strategy for optimization of the anaerobic digestion treatment, was presented for each country, together with advanced biorefinery approaches to wastewater treatment and resource recovery.
\end{abstract}

Keywords: waste management; wastewater; sewage sludge; organic waste; anaerobic digestion; co-digestion; biorefinery; resource recovery

\section{Introduction}

The paradigm of waste and wastewater management has changed in recent years from mere waste disposal to resource recovery. Increasing waste generation due to population growth and increasing living standards requires an efficient waste management system, encompassing waste prevention, waste recycling and waste detoxification, including the separation and conversion of heavy metals and organic contaminants. For organic waste and wastewater, this means (a) recovering the energy content of carbon compounds, (b) recovering nutrients such as nitrogen and phosphorous and (c) separating and neutralizing toxic compounds such as microplastics or pharmaceuticals from waste and wastewater.

Thus, wastewater treatment plants (WWTP) represent a clear example of the shift towards resource recovery, and they are now seen as water resource recovery facilities (WRRF) [1] or wastewater biorefineries (WWBR), aiming to link the treatment of wastewater to the production of renewable bioproducts that can maximize resource recovery. A WWBR revolves around conversion of the organic carbon and the recovery of nutrients from the wastewater as value-added products. Additionally, the revenues from these bioproducts should be enough to guarantee economic feasibility of the wastewater treatment and generate a further income. At the same time, the effluent from the initial wastewater is clean enough to meet the corresponding discharge policies [2].

After the clarification of wastewater in conventional wastewater treatment plants, organic and inorganic compounds are mainly found as the major byproduct in sewage sludge [3]. Sewage sludge has a potential value that can be recovered in the form of energy 
or resources, depending on the applied technology [4]. The specific amount and composition of sewage sludge is dependent on the wastewater and the treatment technology applied. In modern sewage treatment plants, consisting of at least a mechanical and a biological purification stage, sewage sludge can be divided into primary and secondary sludge, according to its generation during wastewater treatment. Primary sludge contains the solids that form sediment in the primary settling tank (mechanical purification). Secondary sludge, commonly known as waste-activated sludge (WAS) from the biological purification stage, is composed of a variety of microorganisms that remove most of the organic matter in an aerated process and settle in the secondary clarifier. A total of 10.13 million tons in dry solids of sewage sludge were estimated in 2008, but only in Europe, with an expected increase of $30 \%$ until $2020[5,6]$.

A specific regulation regarding management of sewage sludge in the European Union (EU) is still missing; therefore, there is an urgent need to establish a proper management system to reduce the amounts and recover valuable energy and compounds from sewage sludge. The directive concerning urban wastewater treatment only states that the disposal of sewage sludge to surface waters should be phased out and its recycling should be encouraged [7]. Furthermore, it establishes the need to make information regarding the disposal of wastewater and sludge publicly available. Nevertheless, there is a lack of coherent reporting on the generation of sewage sludge within the European countries, with incomplete data sources.

Incineration, for example, is an established thermal technology to yield energy from recalcitrant organic matter from sewage sludge and solid municipal waste, while reducing its volume. Anaerobic digestion (AD), on the other hand, is the most common biological method to recover the energy content of carbon compounds in the sludge by their conversion into methane. While nutrients can be reused in agriculture after biological treatment, they are either lost or bound to ashes after thermal treatment. According to the Sewage Sludge Directive, which regulates the use of sludge on the soil, this can only be done after proper treatment (e.g., biological, chemical or long-term storage) to reduce its fermentability and potential health hazards [8]. In Europe, the produced sewage sludge has different final destinations, such as agriculture $(49.2 \%)$, land reclamation $(12.4 \%)$, incineration $(24.9 \%)$ or landfill $(8.7 \%)$. For comparison, around $65 \%$ of the sludge was destined to agriculture in Scandinavia in 2016 [9,10].

However, sewage sludge contains a rich pool of organic matter (i.e., carbohydrates, proteins and lipids) that could also be biologically fermented for the production of other value-added products, rather than biogas. Moreover, the increasing depletion of natural resources has shifted the research efforts towards green chemical production, in addition to energy recovery, as previously mentioned in WWBR. For instance, sewage sludge has been used for the production of biofuels such as biodiesel [11], and for the production of biopesticides [12], bioplastics [13] or volatile fatty acids [14].

A promising approach to improve sewage sludge valorization is the addition of another organic waste, which can increase the amounts of energy and green chemicals recovered from organic waste and improve the economy of the treatment plant [15]. Moreover, the co-digestion of wastes can overcome problems related to single substrate digestion, such as a lack of micronutrients or imbalanced $\mathrm{C} / \mathrm{N}$ ratio, and favors the growth of a robust and more diverse microbial community [16]. Some examples of organic wastes that can be co-digested are animal manure, agricultural residues, garden waste, sludge from fish farming (manure and excess feed), the organic fraction of municipal solid waste (OFMSW) or slaughterhouse waste. Organic wastes containing biodegradable matter also hold huge potential as carbon resources that can either be used for energy recovery in the form of biogas or as raw material for different bio-based compounds [17].

The management of sewage sludge through anaerobic digestion and co-digestion with other organic waste has been commonly applied in northern Europe, especially for bioenergy production [5]. In fact, Nordic countries have ambitious policies to become fossil-free by 2050, focusing on renewable energy sources, such as wind or bioenergy. In 
2013 , biomass and waste accounted for $18 \%$ of the primary energy production, with an expected further increase to about $35 \%$ by 2050 [18,19]. The proper management of sewage sludge can play a fundamental role in future bioenergy production, apart from resource recovery and its valorization to green chemicals. For that purpose, biorefineries and the co-digestion of wastes will be key players in the future of sludge management [20]. There are several publications in which sludge management is reviewed, focusing on the different available technologies [21,22]. The co-management of sewage sludge with other solids wastes in Europe was also evaluated, presenting the potential benefits of co-composting, co-incinerating or co-landfilling these wastes, for optimization and cost reduction of these technologies [23]. However, incineration is only economically feasible for waste with low moisture content. Likewise, landfilling requires a low moisture content (at least 20-25\% dry matter, DM), and is highly regulated by the European legislation, due to its potentially negative environmental effects [23]. In addition to the treatment and disposal of sludge, the recovery of resources such as nutrients is another important factor to consider during its management. Different technologies have been and are still being developed for that purpose, as reviewed in several publications [24,25]. However, a life cycle assessment (LCA) is often required to evaluate the environmental impact of the nutrient recycling [26].

The chemical composition of sludge can vary significantly depending on the applied wastewater treatment, and the geographical location. For that purpose, the available technologies for sludge management and resource recovery should be tailored to the characteristics of the sludge. Potential substrates for anaerobic co-digestion with the sludge have been previously reviewed [27], but there is a lack of publications targeting Scandinavian countries, in which the co-digestion of organic waste for biogas production has been taking place for several years [28]. These established systems present an opportunity to include sludge in co-digestion, which could be an interesting approach to centralized organic waste management. In this paper, focus is on Scandinavian countries (i.e., Denmark, Norway and Sweden), to review the current technologies applied for sludge management. Moreover, due to the Scandinavian experience with co-digestion, other relevant organic waste fractions were identified, which could potentially be co-digested with the sludge. A full-scale case study is presented for each country, in which sewage sludge is co-digested with another organic waste, emphasizing the advantages of co-digestion. In addition, several advanced biorefinery approaches to wastewater treatment and resource recovery are included. Therefore, the findings from this review paper could enhance the establishment of robust co-digestion systems, key players in urban organic waste management.

\section{Sewage Sludge Management in Scandinavia}

The management of sewage sludge focuses on the reduction in sludge volume and weight, while decreasing the potential health hazards of the waste. The process can be divided into four steps: thickening, treatment or stabilization, dewatering and final disposal (Figure 1). The first step, sludge thickening, increases the solids content and reduces the water volume quickly, which minimizes the unit load on the following treatment. Different technologies can be applied for sludge thickening, such as gravity settling (as presented in Figure 1) or polymer addition. Secondly, sludge is stabilized, with the main purpose of reducing the pathogens and eliminating the odors. However, the type of treatment applied to the sludge depends on the volume of sludge generated and the disposal method, while the disposal method is influenced by the regulatory constraints.

There are three main stabilization methods that can be applied to the sludge: alkaline, aerobic (thermophilic) or anaerobic (thermophilic) stabilization [29]. The first one, alkaline stabilization, is achieved by the addition of lime to dewatered sludge to increase the $\mathrm{pH}$ to around 12, which, in turn, rapidly increases the temperature of the sludge. A typical dose is $550 \mathrm{~kg} \mathrm{CaO}$ per ton sludge DM, for sludge with a 25\% DM content [29]. This process leads to ammonium release and the high temperature also provides good hygienization of the sludge, avoiding microbial activities that can lead to odor production. On the other hand, aerobic stabilization, also called aerobic digestion, can be considered a continuation of the 
activated sludge process, in which microorganisms consume the remaining organic matter. Finally, anaerobic stabilization, also called anaerobic digestion (as presented in Figure 1), consists of the degradation of sludge under anaerobic conditions, generating methane and carbon dioxide as final products. An advantage of anaerobic digestion compared to other stabilization methods is the production of methane, which can be used as an energy source to run the WWTP [30].

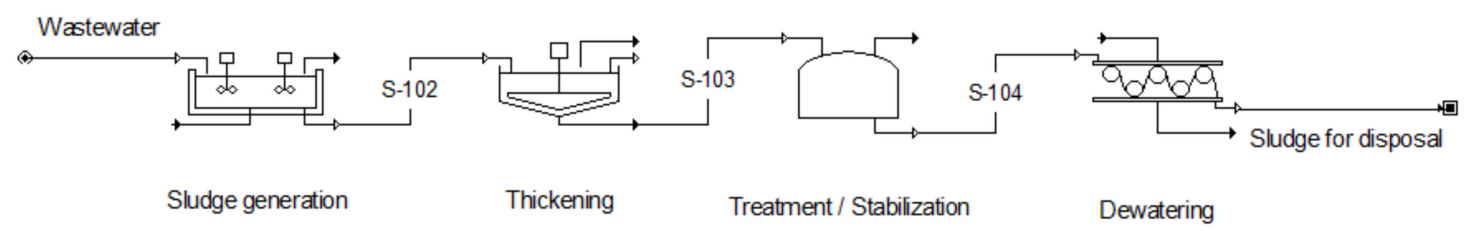

Figure 1. Scheme of sludge management.

Subsequently, sewage sludge is dewatered to improve handling of the waste, while meeting the disposal regulations. Different technologies can be applied for dewatering, such as centrifugation or drying beds. Finally, the stabilized and dewatered sludge can be disposed using different alternatives: land spreading, landfilling, incineration, etc. Land spreading consists of the addition of sludge to the soil, in order to improve the soil structure, water infiltration, addition of nutrients such as $\mathrm{N}$ and $\mathrm{P}$, etc. Nevertheless, the application of sludge in the soil has to meet the established limits for heavy metals, nitrates, and other pollutants [30]. Moreover, sewage sludge can also be used in the cement and brick manufacturing industries [31].

Depending on the final disposal method, the water content of the treated sludge can vary. For example, around $30-45 \%$ DM content is necessary to incinerate the sludge together with other materials, while $60-90 \%$ DM is required for a separate combustion of the sludge [32]. On the other hand, the common combination of anaerobic digestion for sludge stabilization, followed by dewatering, generates a final product with about $25 \%$ DM, which can be further used for different purposes, such as soil application or composting [33].

Furthermore, there is an increasing interest in novel routes for energy recovery of sewage sludge, such as pyrolysis or gasification. Despite their complex equipment, these thermochemical technologies may present a greater volume reduction and better economic performance [34]. Pyrolysis, for instance, is a process that takes place at high temperatures (between 300 and $700{ }^{\circ} \mathrm{C}$ ) in the absence of $\mathrm{O}_{2}$. It is a versatile technique, as very different products can be obtained: the pyrolytic gas can be burned as fuel to provide heat and electricity, the bio-oil can be used as raw material for the production of chemicals or fuel, and the biochar contains concentrated nutrients, which can be used in soil amendment [35]. However, one of the main drawbacks of these thermochemical technologies is their energy consumption, required for sludge dewatering and drying. The high pressure and temperature required during these processes make them energy-intensive technologies. Therefore, anaerobic digestion seems to be a more suitable technology for a liquid stream such as sludge, in comparison to combustion processes, due to the higher flexibility and lower requirements to handle the moisture content of the feedstock [35].

In addition to energy, nutrients can also be recovered from sewage sludge. The most common method is its use as fertilizer after sludge stabilization due to both the increasing generation of sludge and to the need for fertilizers for agriculture. However, a disadvantage of this approach is the lack of information regarding nutrient content and bioavailability, which makes sludge a low-quality fertilizer compared to conventional fertilizers [25,36]. On the contrary, after pyrolysis, most of the phosphorus and half of the nitrogen remain in the generated char, which is considered a potential fertilizer. While nitrogen is reported to be insoluble, the phosphorus is considered plant-available [37].

It is also worth mentioning that different contaminants, such as microplastics, pharmaceuticals, surfactants and heavy metals, are emerging in wastewater, due to lifestyle 
changes in human society. These contaminants accumulate in the sewage sludge during wastewater treatment, and some of them may not be degraded during sludge stabilization (in anaerobic digestion, for instance) [38,39]. Therefore, a correct final disposal of the sludge should take this into consideration. For example, the spreading of sludge in agricultural land could be a source of contamination, if not properly managed $[40,41]$.

\subsection{Denmark}

With a population of 5.7 million inhabitants and a total area of $42,943 \mathrm{~km}^{2}$, Denmark is the most densely populated Nordic country [42]. This entails a high yearly urban wastewater generation of about $115 \mathrm{~m}^{3}$ per person and more than 140,000 tons DM of sewage sludge [43]. The main Danish wastewater treatment companies provide services to more than 5 million people in the country, and operate 456 treatment plants, which treat more than 670 million $\mathrm{m}^{3}$ of wastewater, with a load of 7.1 million population equivalents (PE) [44]. Almost half of the PE load corresponds to main cities, such as Copenhagen, Aarhus or Aalborg, with the highest population density.

It is estimated that an average of $29 \%$ of the total operating expenses in WWTP correspond to the treatment and disposal of the generated sludge, depending on the treatment method and the quality of the sludge itself. Danish WWTP deal with the surplus sludge by following two steps: sludge treatment, followed by sludge disposal (Figure 2). According to the Danish regulations, sewage sludge can be classified into three different groups: (1) Sludge that is only dewatered before disposal, (2) Sludge that is used for biogas production, followed by dewatering before disposal, and (3) Sludge that is slowly degraded in mineralization beds, usually emptied every 10 years. The second treatment method, anaerobic digestion, stabilizes the sludge and produces biogas that can be used as energy source for the own treatment plant or injected to the grid after upgrading the gas. The remaining fraction, after anaerobic digestion, is then dewatered and disposed. Each wastewater company can decide which type of treatment is applied to the sludge; for example, larger plants usually build a biogas plant to treat their own sludge [44].

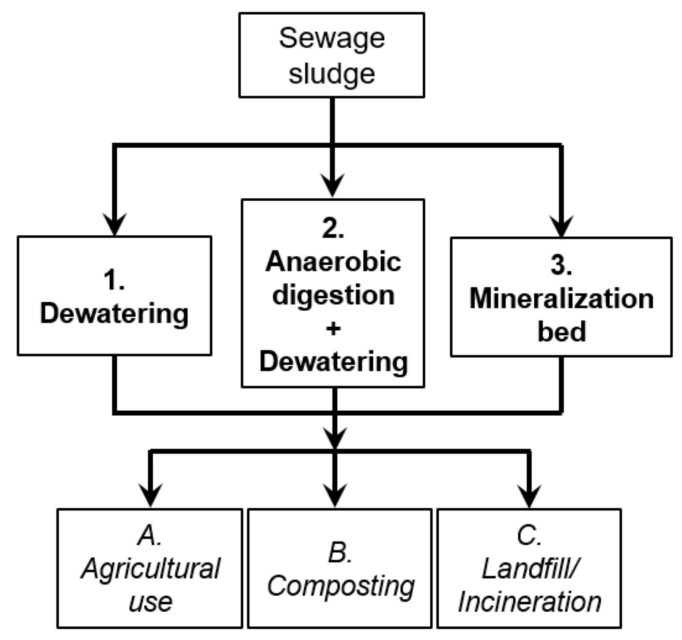

Figure 2. Surplus sludge management in Danish WWTP, according to [43]. The treatment methods are in bold, while disposal methods in italics.

The third technology applied for sludge treatment is mineralization beds, in which the sludge is slowly degraded. Sludge treatment reed beds (STRB) are a common type of drying bed, which have been used in Denmark since 1988. There were about 105 systems in operation in 2015, treating up to 3000 tons DM of sludge [45]. This technology consists of a series of drying beds loaded in turns, with two or three operational cycles of 10-15 years. Over this period of time, the sludge is mineralized by naturally occurring microorganisms, although it is common practice to plant a common reed (Phragmites australis (Cav.) Trin. Ex Steud) to enhance this process. The sludge can achieve a dry solid content of $25-40 \%$, 
compared to typical dewatering processes such as centrifugation (15-20\%) or belt press system $(15-24 \%)$, and is then suitable for land application $[45,46]$. Compared to other systems, mineralization beds have several advantages: besides dewatering, this technology minimizes the sludge volume and improves its quality, since it partially mineralizes the organic matter in the sludge [47].

After treatment of the sludge, using one of the three previously mentioned methods, the sludge is dewatered and disposed of according to its category: (A) Sludge that is spread on farmland, (B) Sludge that requires further treatment, e.g., composting (that needs further sanitation before reutilization, for example, because of high levels of pesticides) and (C) Sludge that is landfilled or incinerated (usually due to a high content of heavy metals, which does not comply with the legislation for sludge application to soil). Based on the pertinent analyses of the sludge and the management strategy, each wastewater company determines the method of disposal. The distribution of the sludge quality depends on the company and region of origin; some only contain A sludge, while in others, it is only C sludge that is incinerated.

\subsection{Norway}

Norway is located at the Western part of the Scandinavian Peninsula, with a population of 5.3 million [42]. A total of $86 \%$ of the population is connected to the municipal wastewater treatment system, consisting of 2714 WWTP ( $\geq 50$ PE capacity). It is estimated that only $1.7 \%$ of the Norwegian land is used for urbanized areas [48], and one fourth of the population lives in rural and mountainous regions. Thereby, there is a high number of small municipal WWTP due to the population distribution, which is spread over the country [49]. Moreover, the remaining population (14\%), not connected to municipal WWTP, is served by private small-decentralized treatment systems $(<50 \mathrm{PE})$, such as septic tanks or infiltration systems [50].

In the last 10 years, sewage sludge production in Norway has increased by $20 \%$, up to a yearly production of approx. 120,000 tons DM. The increasing population and stricter requirements for wastewater treatment before discharge to water recipients are the main causes. Sewage sludge has been employed in Norway as a soil enhancer since the late 1970s, and the Norwegian wastewater sector has more than 30 years of experience with sludge stabilization and hygienization methods. The most common methods used in Norway for sludge stabilization and hygienization are presented in Figure 3.

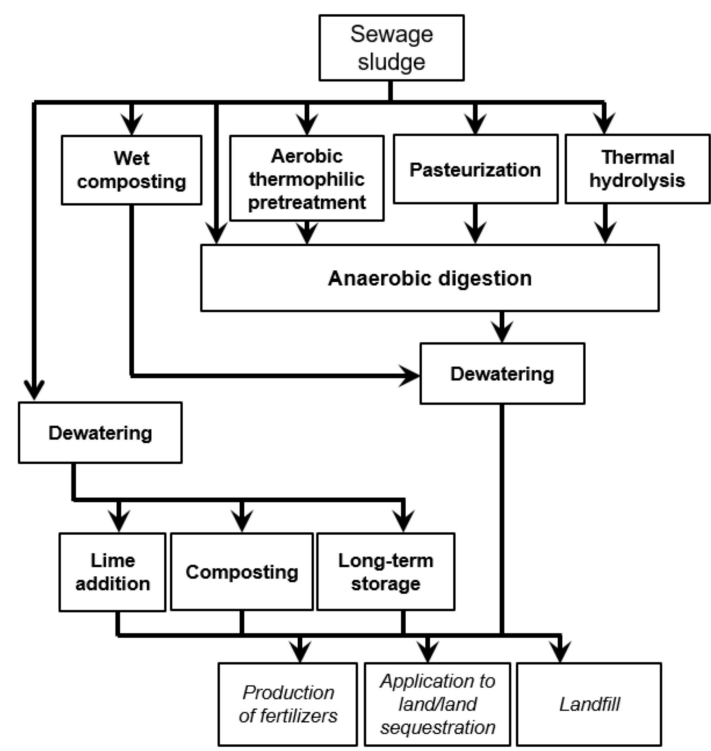

Figure 3. Sludge management practices in Norway (adapted from [51]). The treatment methods are in bold, while disposal methods are in italics. 
There are 137 registered facilities that treat sewage sludge in Norway [52]. Larger facilities usually apply the following processes: thermophilic aerobic pre-treatment and mesophilic anaerobic digestion, pasteurization and mesophilic anaerobic digestion, thermophilic anaerobic digestion, and thermal hydrolysis, a process that was first applied to sewage sludge by the Norwegian company Cambi, combined with mesophilic anaerobic digestion. At the smaller facilities, the following process and process combinations are more common: lime stabilization of dewatered sludge, composting, long-term storage and simple windrow composting, while wet composting is currently only applied at one municipal WWTP [40].

National organic fertilizer regulations establish limit criteria when using the sewage sludge as soil enhancer $[53,54]$. The limits comprise the content of heavy metals, salmonellabacteria and infective parasites, as well as a limit of fewer than 2500 thermotolerant coliform bacteria per gram of dried sludge.

\subsection{Sweden}

Sweden, with a population of 10.2 million people, is the largest country of Scandinavia, with most of the population living in the southern part [42]. An average of $110 \mathrm{~m}^{3}$ wastewater were generated per person in 2018, and 212,000 tons DM of sewage sludge were produced in total $[55,56]$. More than 1.100 million $\mathrm{m}^{3}$ of wastewater are treated every year in 453 WWTP across the country; of these, only $5 \%$ of the plants treat wastewater from $>100.000$ PE, while $60 \%$ of the WWTP have a size of $<10.000$ PE [56].

In Sweden, 20\% of the energy consumed in a WWTP relates to sludge treatment [32]. As presented in Figure 4, the most common stabilization method in larger WWTP is anaerobic digestion at mesophilic conditions, followed by dewatering in centrifuges (and the supernatant after dewatering is returned to the WWTP). Only 135 WWTP in Sweden have a digester for biogas production from sludge, since many of the WWTP are small and it is not profitable to build one [57]. Smaller WWTP, on the other hand, usually dewater the sludge in mineralization beds [33]. A third treatment option for sewage sludge is lime addition, which is common in small plants that do not have a digester. The stabilization of sludge with lime is an exothermic process that reduces the organic matter content, achieving low moisture contents (less than 10-15\%), due to the high temperatures achieved [58].

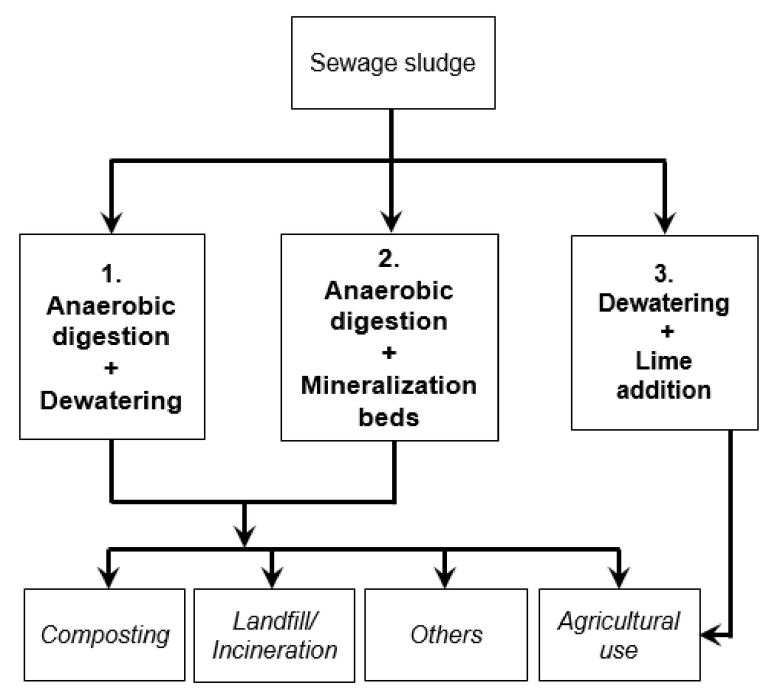

Figure 4. Common sludge management in Sweden (adapted from [33]). "Others" stands for land restoration and construction land. The treatment methods are in bold, while disposal methods in italics.

After treatment of the sludge, there are different options for its disposal (Figure 4). The most common uses of sludge are in the production of plant soil, landfill cover or as a fertilizer on fields. However, the amount of sludge used as fertilizer has stayed 
the same for the last decade, at around 40\% [56]. This application has been a topic of ongoing debate in Sweden in recent years [59]. Recently, the Swedish government has proposed a ban on spreading sewage sludge in agriculture, due to the low nutrient content and plant availability, but encouraged the recovery of nutrients from ash after sludge incineration $[24,59,60]$. Moreover, the government also considers the increasing content of potential harmful substances, such as microplastics, and the lack of available land for sludge spreading, as justifications to search for other sludge uses.

In recent decades, the quality of the sludge in Sweden has increased, mainly through preventive actions (i.e., reducing the amount of unwanted substance before they reach the wastewater treatment). However, this strategy is easier to apply to industries and companies than to households. One example of this approach is the REVAQ-certification, a quality control system under which the WWTP committed to reducing the number of unwanted substances. Around half of the wastewater in Sweden is treated at REVAQaccredited WWTP [56].

\subsection{Comparison of Sludge Management and Quality}

As presented in Table 1, the sludge generated after wastewater treatment is commonly valorized via anaerobic digestion and dewatering in all three countries. However, different combinations of these technologies are applied in each country, depending on the sludge composition and current legislation. Disposal of the sludge, on the other hand, follows similar routes in the three countries (i.e., soil application as biofertilizer or soil amendment).

Table 1. Summary of sludge treatment and disposal methods in Scandinavian countries. References are presented in square brackets. AD: Anaerobic digestion; DK, Denmark; NO, Norway; SE, Sweden.

\begin{tabular}{cccc}
\hline & DK [43] & NO [51] & SE [33] \\
\hline Treatment method & & \\
Dewatering & $X$ & $X$ \\
AD + Dewatering & $X$ & $X$ \\
Mineralization bed & $X$ & $X$ \\
AD + Mineralization bed & & $X$ & \\
Dewatering + Lime addition & & $X$ & \\
Thermal treatment + AD & & $X$ \\
Disposal method & & $X$ \\
Agricultural use & $X$ & $X$ \\
Composting & $X$ & $X$ \\
Landfill & $X$ & $X$ \\
Incineration & $X$ & $X$ \\
Other & $X$ & & \\
\hline
\end{tabular}

Other methods to manage the dewatered sludge are landfill or incineration, which are applied differently, depending on the country. A summary of the final destination of the sludge is presented in Table 2, together with the generated amounts per country.

Table 2. Summary of sludge generation and final destination. Soil application comprises its use as fertilizer and plant soil. References are presented in square brackets. DK, Denmark; EU, Europe; NO, Norway; SE, Sweden.

\begin{tabular}{cccccc}
\hline & Units & DK [43,61] & NO [62] & SE [55] & EU [6,9] \\
\hline Generated sludge & Tons DM/year & 140,000 & 112,000 & 212,000 & $13,000,000$ \\
Final destination & $\%$ & & & & \\
Soil application & & 64.9 & 82.4 & 64.5 & 61.6 \\
Incineration & & 28.2 & 0.6 & 1.3 & 24.9 \\
Landfill & & 0.8 & 6.3 & 18.2 & 8.7 \\
Other & & 6.1 & 10.7 & 16.0 & 4.9 \\
\hline
\end{tabular}

It is worth noting that the total generated amount of sewage sludge in tons of DM is not directly comparable, as it depends on the origin, wastewater treatment type, etc. After treatment of the sludge, it can be disposed of and serve different purposes, as presented 
above. Both Denmark and Sweden use $65 \%$ of the total sludge for agricultural application, which is very similar to the European average. In Norway, on the other hand, more than $80 \%$ of the sludge is finally used as fertilizer or plant soil. It is worth mentioning that the second most common strategy for sludge management in Denmark is incineration, using almost $30 \%$ of the sludge. This could be due to a high heavy metals content in the sludge, or other contaminant products, which decrease its quality. Nevertheless, Denmark has a long tradition of incinerating waste, following a waste-to-energy approach. Around 50\% of the Danish municipal solid waste is incinerated [63], and the current waste incineration plants generate approx. $20 \%$ of all district heating and $5 \%$ of the electricity consumption in the country [64]. Despite the establishment of incineration as energy recovery technology, it is an energy-intensive process, as the energy recovery potential during sole sludge incineration is lower than the energy content of its organic matter, due to the energy required to dewater the sludge [65].

As presented in Table 2, the classic uses of sewage sludge are land application, energy recovery (i.e., incineration) and landfill. However, landfilling is an outdated practice for waste disposal (and the least preferable option in the EU's waste hierarchy), with negative impacts on the environment and the economy [66]. Moreover, the European Landfill Directive sets the target to reduce the landfilling of all waste, suitable for recycling or energy recovery, from 2030 [67].

The traditional valorization of nutrients from the sludge consists of their reuse for agricultural purposes, such as soil fertilizer. Nevertheless, there are specific European and national policies, which determine the maximum concentration of certain components present in the final sludge product, such as N, P or heavy metals, in order to avoid their accumulation in the soil [40]. A summary of the different compounds that affect the quality of the sludge is presented in Table 3, including the national average values of sludge in Scandinavian countries.

Table 3. Summary of sludge average composition of nutrients and heavy metals, including the maximum allowed concentrations of the different compounds (in italics). References are presented in square brackets. DK, Denmark; EU, Europe; NO, Norway; SE, Sweden.

\begin{tabular}{cccccccc}
\hline Compound & \multicolumn{2}{c}{ DK } & NO & & SE & EU \\
\hline $\begin{array}{c}\text { mg/kg } \\
\mathbf{D M}\end{array}$ & $\begin{array}{c}\text { Average } \\
{[68,69]}\end{array}$ & $\begin{array}{c}\text { Max. } \\
\text { Allowed } \\
{[70]}\end{array}$ & $\begin{array}{c}\text { Average } \\
{[71,72]}\end{array}$ & $\begin{array}{c}\text { Max. } \\
\text { Allowed } \\
{[72]}\end{array}$ & $\begin{array}{c}\text { Average } \\
{[73]}\end{array}$ & $\begin{array}{c}\text { Max. } \\
\text { Allowed } \\
{[72]}\end{array}$ & $\begin{array}{c}\text { Max. } \\
\text { Allowed } \\
{[8]}\end{array}$ \\
\hline $\mathbf{N}$ & 30,000 & & 30,000 & & 46,000 & & \\
$\mathrm{P}$ & 20,000 & & 15,000 & & 26,500 & & \\
$\mathrm{Cd}$ & 0.9 & 0.8 & 0.6 & 0.4 & 0.7 & 2 & $20-40$ \\
$\mathrm{Cu}$ & 295.5 & 1000 & 164.8 & 50 & 353.3 & 600 & $1000-1750$ \\
$\mathrm{Ni}$ & 23.9 & 30 & 12.9 & 20 & 16.8 & 50 & $300-400$ \\
$\mathrm{~Pb}$ & 52.8 & 120 & 13.8 & 40 & 16.2 & 100 & $750-1200$ \\
$\mathrm{Zn}$ & 1046 & 4000 & 391.1 & 150 & 562 & 800 & $250-4000$ \\
$\mathrm{Hg}$ & 1 & 0.8 & 0.3 & 0.2 & 0.5 & 2.5 & $16-25$ \\
$\mathrm{Cr}$ & 24.5 & 100 & 16.9 & 50 & 22.1 & 100 & - \\
\hline
\end{tabular}

The average concentrations of heavy metals in the sludge are also presented in Table 3, as well as the maximum allowed concentration in the sludge, according to national and European legislation, for its use in agriculture. The mentioned concentration is an average and does not necessarily indicate that the sludge is applied to the soil. The European limits for heavy metals concentration in the sludge were implemented in the Sewage Sludge Directive in 1986, but each country established national limits following the European guidelines.

Nevertheless, stabilized and dewatered sludge may be a low-quality fertilizer, depending on its origin, composition and potential contaminants. Additionally, the current legislation does not consider microplastics or pharmaceutical residues in the sludge. Moreover, the revised EU Fertilizer Regulation, in 2019, excluded sewage sludge from the production of market organic fertilizers [74]. Other nutrient-recycling alternatives, considered in the EU Fertilizer Regulation, include struvite production, biochar after pyrolysis or 
direct extraction from ashes after incineration, as mentioned in Section 2.3. The recovery of $\mathrm{P}$ from sludge ashes is gaining increasing attention, and a commercial plant was built in Sweden for that purpose. With their patented process, clean commercial phosphorus products are produced, such as Calcium Phosphate, Ferric Chloride or Aluminium Hydroxide [75]. These are promising alternatives for nutrient recovery (especially P) from sludge, although they imply a compromise between the input energy required to treat the sludge with these technologies and the resources that can be recovered.

\subsection{Environmental and Economic Aspects of Sludge Management in a Circular Bioeconomy}

With the world shifting to a circular economy and sustainable development, the generation of waste should be minimized, and the value of products and resources should be maintained for as long as possible in the economy. Accordingly, the European Commission (EC) set ambitious targets for a circular economy in 2014, with different legislative proposals [76], including the first Circular Economy Action Plan in 2015, which aimed at the transition to a more circular economy [77]. In this context, the increasing generation of sewage sludge and its management can play a crucial role, due to its potential as a raw material for green chemicals' production and nutrient recovery. Therefore, economic and environmental evaluations of the different sludge management technologies and resource recovery opportunities are essential, in order to integrate them into a circular economy. A summary of the main economic and environmental considerations for the previously reviewed technologies is presented in Table 4. As mentioned in Section 2.4, incineration is an energy-intensive process, and the recovered energy from sole sludge incineration does not offset the required energy [65]. Landfilling, on the other hand, does not require a high investment, but the generated landfill gas emissions have negative environmental effects, in addition to the underground water pollution.

Table 4. Summary of the economic and environmental aspects of different sludge management strategies.

\begin{tabular}{|c|c|c|}
\hline Technology & Environment & Economy \\
\hline \multirow[t]{5}{*}{ Anaerobic digestion and soil application } & Recovery of organic matter & Biogas production for heat and electricity \\
\hline & Nutrients can be reused & $\begin{array}{l}\text { Recalcitrance of sludge may reduce biogas } \\
\text { yield }\end{array}$ \\
\hline & Greenhouse gas emissions reduction & Replacement of chemical fertilizers \\
\hline & $\begin{array}{l}\text { Potential contaminants and low nutrient } \\
\text { bio-availability }\end{array}$ & \\
\hline & & Low investment and energy consumption \\
\hline \multirow[t]{3}{*}{ Mineralization beds } & Organic matter mineralization & Volume reduction \\
\hline & Sludge stabilization & Large land extension required \\
\hline & Released water treated via percolation & Volume reduction (handling costs reduction) \\
\hline \multirow[t]{4}{*}{ Incineration } & Energy recovery & Ashes disposal \\
\hline & Thermal destruction of pathogens and odours & Energy intensive \\
\hline & Potential gas emissions & \\
\hline & Nutrients not recovered & \\
\hline \multirow[t]{4}{*}{ Pyrolysis } & Energy recovery & Volume reduction (handling costs reduction) \\
\hline & Thermal destruction of pathogens and odours & Energy intensinve \\
\hline & Nutrients recovered in biochar & Complex equipment \\
\hline & Less pollutant $\left(\mathrm{O}_{2}\right.$ absence $)$ & \\
\hline \multirow[t]{3}{*}{ Landfill } & Landfill gas emissions & Low investment \\
\hline & Low sludge stability (odours, pathogens, etc.) & Large land extension required \\
\hline & Underground water pollution & Linear economy approach \\
\hline
\end{tabular}

For the environmental aspect, LCA can be applied to assess the impact of the different sludge management technologies. In fact, several publications compared the environmental performance of different approaches, such as incineration, anaerobic digestion or pyrolysis [78,79], and pyrolysis was found the best waste-to-energy technology [80]. Nevertheless, a complete LCA is highly dependent on the underlying assumptions, as well as on the set boundaries and selected impact categories [81]. Some of the common impact 
categories are climate change, water depletion, freshwater ecotoxicity or agricultural land application [78].

Simulation processes are key tools in order to evaluate the economic feasibility of the processes and different scenarios. For that purpose, it is necessary to set the boundaries of the simulation (similarly to an LCA), while standardizing the conditions needed for a comparison of different scenarios. One example would be to estimate the treatment cost per ton of waste material, or per $\mathrm{m}^{3}$ of produced biogas. Despite the increasing research interest in resource recovery from wastewater treatment facilities, there is a lack of economic studies that evaluate large-scale plants for sludge management. For example, bioplastics production from sewage sludge was evaluated, coupling this process to a current WWTP. It was found that the size of the WWTP had a high effect on the economic feasibility of the plant, as well as the methane selling price [13]. However, the social impact of the different technologies should also be evaluated, in addition to environmental and economic considerations, in order to perform a full sustainability assessment.

\section{Other Representative Organic Wastes in Scandinavia}

The management of organic or biodegradable waste has changed in recent years, shifting from landfill to its use as raw material for the production of bioenergy or green chemicals, in the framework of a circular economy. The EC defines bio-waste as biodegradable garden and park waste, food waste from households, canteens, restaurants, food processing plants, etc., but it does not include agricultural residues, manure or sewage sludge [66,82]. Between 118 and 138 million tons of bio-waste are annually produced in Europe [83], of which 86 million tons came from municipal waste (i.e., food and garden waste) in 2017 [84]. The current collection of bio-waste differs between countries, but the EC set 2023 as the target for mandatory separated bio-waste collection in Europe [82]. Of the total bio-waste generated in Europe, an average of 40\% was still landfilled in 2010 [83], but the EC encouraged the biological treatment of bio-waste by anaerobic digestion or composting [82]. In addition, a gradual reduction in bio-waste landfilling was proposed [85], establishing a limit of $10 \%$ by 2035 [86]. To achieve higher shares of bio-waste supplied to specific treatments for energy and resource recovery, the design of a bio-waste management system with high waste collection shares has to be established in the first place. In this section, different representative organic wastes from Denmark, Norway and Sweden are presented.

\subsection{Denmark}

In addition to sewage sludge from wastewater treatment, other representative organic wastes generated in Denmark are livestock manure, the OFMSW or agricultural waste. OFMSW consists of the bio-waste from households, i.e., garden and food waste. Denmark was the country with the highest bio-waste generation in 2017, with $375 \mathrm{~kg} /$ person, compared to the European average of $180 \mathrm{~kg} /$ person [84]. A total amount of 439,000 tons food waste was generated in Denmark only in 2018, compared to 207,000 tons in 2014 [87]. The recent increase in organic waste is not due to an increase in its generation, but to higher shares of the separate collection of organic waste in municipalities and industries [88]. This entails the necessity of a waste treatment system tailored to the quantity, composition, quality and final use of organic waste.

In the Copenhagen area, for example, after being collected, the OFMSW is transported to a plant, where it is pretreated to produce the so-called biopulp. This material is obtained after a mechanical pretreatment step and is intended for biogas production or composting. The value of the biopulp depends on different characteristics, such as the quality of the material, DM content or biogas potential, but the average market price of biopulp with a $15-16 \%$ dry content is about $100 \mathrm{kr}$./ton, roughly corresponding to $13.4 € /$ ton [89].

Livestock manure is another representative organic waste in Denmark, with an estimated production of 35 million tons per year [90]. The high livestock manure production in Denmark is, in part, due to its role as major exporter of pork meat. A total of $80 \%$ of the 
generated manure is in the form of slurry, which is mainly used as a substrate for energy generation. Following the Danish environmental policies, by 2020 , at least $50 \%$ of the total manure production should be treated for energy purposes (i.e., anaerobic digestion, gasification, pyrolysis or combustion) before it can be spread as fertilizer [90]. Biogas plays an important role in bioenergy generation in Denmark as a way to manage any type of organic waste, such as manure or sewage sludge. Most of the biogas plants are manure-based, which represents more than $75 \%$ of the input material to the plant. In the case of sewage sludge, anaerobic digestion of the material usually takes place locally in a digester in the wastewater treatment plant.

\subsection{Norway}

According to Statistics Norway, around 200,000 tons of food waste were collected in 2018, representing approx. $9 \%$ of the total waste produced by an average Norwegian household [91]. Each municipality chooses their own type of collection system and waste fraction, which vary between municipalities. Overall, coverage with recycling collections is high and a range of different recyclable fractions can be recovered. A total of $70 \%$ of the municipalities offer the separate collection of bio-waste, $87 \%$ of plastic packaging and $98 \%$ of paper packaging. However, there are different approaches to food waste collection in Norway. In 2012, the City of Oslo made source sorting of food waste mandatory, moving towards 50\% recycling by 2018. The OptiBag system is used, based on different color bags for the main three household fractions-food waste, plastics and rest waste- to be separated in an optical separation plant with the subsequent respective treatment of the three different fractions [42]. The food waste fraction accounts to 18,700 tons and is supplied to an anaerobic digestion plant.

In Norway, the main other relevant organic waste types are fish sludge and animal manure. Over the last 10 years, the Norwegian aquaculture production has doubled, from about 600 thousand tons to over 1.2 million tons [92], and it has been anticipated to increase fivefold by 2050. Fish waste and sludge originate from extensive fish farming activity, which is mostly located at the country's West and Northern coasts. From salmon farming only, it is estimated that approx. 400,000 tons of fish sludge, composed of fish manure and feed surplus, are produced every year in Norway [93]. A recent study showed that, if all fish production was to be transferred from the sea to closed aqua systems on land, approx. $2,145,000$ tons of sludge with $10 \%$ DM would be produced per year. This waste would translate into $0.8 \mathrm{TWh}$ as biogas or $1.2 \mathrm{TWh}$ if incinerated (less than $1 \%$ of the total energy consumption) [94]. Organic wastes of animal origin are not only energy-rich substrates but also a source of important nutrients such as nitrogen and phosphorus, and therefore, at present, key actors in the circular economy concept. For instance, fish sludge has a phosphorus content of approx. 2-3\% DM and a nitrogen content of $6 \% \mathrm{DM}$, while animal manure possesses a phosphorus content in the range of $0.9 \%$ DM $[94,95]$.

\subsection{Sweden}

In Sweden, the collection of food waste as a separate fraction in households is still rising: 73\% of Swedish municipalities sorted food waste from households already in 2016, which increased to $77 \%$ in 2017 [42] and 82\% in 2019 [96]. The biological treatment of household organic waste has also followed an increasing trend since 1975, when only 60 thousand tons were treated, compared to 686 thousand tons in 2019. Organic waste from households is composed of both food waste and garden waste, and food waste represents more than $61 \%$ of the total municipal waste amount [96]. Anaerobic digestion is the main technology applied for its biological treatment, obtaining biogas as energy resource. A total of 0.18 TWh of biogas as transportation fuel, heat and electricity were generated in 2019 from organic waste sorted in households (less than $1 \%$ of the total energy consumption). There is a rising trend of waste sorting, which, combined with the optimization of its biological treatment, will only result in higher green energy generation. 
About 1700 tons of biofertilizer were produced in 2019 from the biological treatment of organic household waste, $99 \%$ of which was used on agricultural land [96]. Moreover, 30\% of this biofertilizer was approved for use within organic farming. In Sweden, biofertilizer produced from pure sources, such as sorted food waste, can be labelled as a product that complies with certain quality standards, a certification system from Avfall Sverige in collaboration with the agricultural and food industry, manufacturers and researchers, among others. Biofertilizer, produced from the co-digestion of different organic wastes such as manure or garden waste, can also be certified, but not from sewage sludge digestion [97]. Certification of the product is voluntary, but almost $82 \%$ of the biofertilizer produced in 2019 from organic wastes other than sewage sludge was certified [96].

\section{Co-Digestion Concepts of Organic Wastes for Higher Energy Yields and Production of Green Chemicals}

Examples of relevant organic wastes that can be co-digested with sewage sludge for its valorization are OFMSW, fish waste or even the scum produced during wastewater treatment [35]. As previously mentioned, co-digestion can improve the efficiency of the process, due to the synergistic effect of the microbial communities [15]. Moreover, it can reduce possible inhibitory compounds of the wastes [98]. The co-digestion of different organic wastes for biogas production has been applied in Danish manure-based biogas plants since the 1980s. The co-digestion concept has been increasingly applied in recent years in Norway, and some of the biggest Norwegian biogas plants are treating (or being designed to do so) more than one substrate at present. From the total of 43 biogas plants, eight treat food waste, alone or in combination with sewage sludge/animal manure, while seven plants combine sludge with other organic resources, such as fish waste, forestry residues or animal manure [99].

A description of different case studies where another organic waste is added to sewage sludge, is presented in the next section, as well as current examples of sewage sludge management strategies in Denmark, Norway and Sweden.

\subsection{Billund Vand, Denmark. Co-Digestion of Sewage Sludge with OFMSW and Organic Industrial Waste}

An example of co-digestion takes place in Billund, a municipality located in central Jutland, the mainland of Denmark. Billund Vand, in charge of wastewater treatment, has been producing biogas from the co-digestion of organic wastes and sewage sludge since 1996. In this plant, organic household waste and organic industrial waste (OIW) are added to the sewage sludge, which are anaerobically digested to produce biogas. The citizens of Billund municipality have been effectively sorting organic household waste since 1997, which is transported from the collection points to the plant. Organic household waste is collected in special paper bags, which do not degrade with the moisture of the waste, but can take part in the anaerobic digestion [100]. In addition, the waste passes through a magnetic separator to make sure there are no metal scraps. The other organic waste is OIW, which consists of flotation fat from the food processing industry. A total of 48,000 tons of waste is treated annually, of which sewage sludge represents $63 \%$, organic household waste $4 \%$ and OIW 33\%. The produced biogas, around 1.28 million $\mathrm{m}^{3}$, is used for electricity and heat production, generating a 50\% energy surplus in the plant. Electricity is sold to the public grid and the heat is used to heat the plant. Additionally, the digestate after AD is dewatered in a screw press, the rejected liquid is sent to the WWTP again, and the fiber fraction $(20-25 \% \mathrm{DM})$ is used as fertilizer by the farmers. Nevertheless, the national policies limit the application of digested OFMSW as fertilizers, requiring a previous hygienization process at $70{ }^{\circ} \mathrm{C}$ degrees for $1 \mathrm{~h}$, in order to ensure there are no present bacteria in the fertilizer [70].

In 1993, the first pilot project to sort OFMSW started, which was consolidated in 1997. The sorting rate is extremely good, since only $1 \%$ of the collected fraction is rejected [100]. The success is largely due to the motivation of the citizens, which are responsible for the proper sorting of the waste. Billund was the first municipality in the country which used 
OFMSW for biogas production, a currently increasing trend in the rest of the country. Despite the current effectiveness of the system, the plant initially faced some technical challenges: the presence of sand and bones in the waste broke the rotatory pumps only after 14 days of operation and the heat exchanger capacity had to be increased. However, the system currently uses centrifugal pumps and has run smoothly since 2001 [100]. The process is also centralized, meaning that the residues from different locations are treated in the same plant. The successful treatment of different types of wastes is very socially accepted in the region, which can help increase awareness of the need of proper wastesorting in the rest of the country.

\subsection{IVAR, Norway. Co-Digestion of Sewage Sludge with Fish Sludge}

On the Norwegian west coast, an association of municipalities aims to digest fish sludge, as well as other organic waste fractions, with their municipal sludge. IVAR IKS was stablished in 1979 as an inter-municipal organization to treat water, wastewater and waste from the Stavanger region. The central wastewater treatment plant at Nord Jæren (SNJ) in Randaberg, near Stavanger, is the biggest waste treatment plant in this region [101]. In addition to SNJ, Grødaland is the newest and largest biogas plant built by IVAR in Hå, Rogaland, opened in April 2017. This is one of Norway's biggest biogas plants to date and is dimensioned to treat 22,600 tons DM/year of both regional sewage sludge and OFMSW. The addition of other substrates as fat from the neighboring dairy industry and fish sludge is currently being considered.

SNJ opened in 1992 as a chemical wastewater treatment plant and was upgraded to a biological one in 2018. The mesophilic biogas plant produces methane from the co-digestion of OFMSW and sewage sludge, currently testing the addition of some fish sludge to the mix. Research trials were performed on sewage sludge co-digestion, with up to $30 \%$ in volatile solids (VS) from fish sludge, obtaining a 35\% increase in the methane production [102].

The produced biogas at the plant is upgraded to biomethane and injected to the gas grid, while the digested sludge is dewatered in centrifuges and dried with steam (and hygienized in the process, so it can be used as fertilizer). The dried sludge is then used for the production of biopellets as soil improver or fertilizer production by nutrient addition [101]. In fact, SNJ was the first plant in Europe to produce a complete fertilizer from sewage sludge. IVAR is very interested in improving the recirculation of nutrients in the region and, therefore, also invests in the addition of dry fish sludge as a nitrogen source for the already-produced, sewage-sludge-based organic fertilizer (MINORGA@ pellets). The factory that produces these pellets is located in the same area as the SNJ plant, and based its technology on IVAR's 20 years of experience with drying and pelletizing sludge. The MINORGA@ pellets are produced by adding N, P and $\mathrm{K}$ to the dried sludge, adapting the amount of nutrients to the customer's needs. Moreover, the content of heavy metals is closely monitored to ensure compliance with pertinent regulations [103].

\subsection{Gryaab, Sweden. Co-Digestion of Sewage Sludge with Grease and Food Waste}

In Sweden, several plants for co-digestion of different organic wastes exist, but not many treat sewage sludge together with other organic waste. One example is Ryaverket WWTP, which belongs to Gryaab, a municipally owned company. This plant receives the wastewater collected from several municipalities surrounding Gothenburg and treats the generated sludge together with other organic wastes. Digestion of the sewage sludge takes place since 1990 and co-digestion with fat and food waste since 1996 [57]. Two organic wastes are added to the digester in order to increase the biogas yield: grease from grease separators in catering kitchens, restaurants, etc. and food residues from the food industry and restaurants, as long as it is not classified as animal by-product. Gryaab is licensed to receive and treat up to 70,000 tons of organic waste every year, although only $22 \%$ of this amount is currently treated [104]. In addition, the waste must be pumpable and should not affect the quality of the sludge. Digestion of the wastes takes place in a series of operations, 
in which the substrate is treated in the two first digesters. The third digester in the plant is used as storage of the digested sludge before it is drained in the screw press.

The biogas generated in the process is stored in a chamber and sent to the upgrading facility $3 \mathrm{~km}$ away at Arendal, which belongs to Gothenburg Energy, via long pipes. In this plant, the biogas is chemically upgraded using the Cooab ${ }^{\circledR}$ technology to capture the carbon dioxide present in the gas, and the purified gas is then compressed and sold as vehicle fuel [105]. The digested sludge after anaerobic digestion is dewatered via screw press and polymer addition, followed by different uses depending on its quality. Samples of digested sludge are analyzed to verify that it meets the guidelines of the REVAQ quality system [104], the certification system used in WWTP that aims to reduce the flow of hazardous substances [106]. If the sludge complies with the requirements, it is hygienized via long-term storage for six months and then applied to agricultural land. In the case that the sludge does not meet the requirements or cannot be disposed for agricultural use, it is used for the production of different soil products. The sludge is composted, mixed with bark and chippings and finally mixed with rock flour and sand. The final product is used for golf courses, coverage of landfills or construction, among others [57].

\subsection{Advanced Biorefinery Scenarios for Wastewater Treatment and Resource Recovery}

Despite the established energy recovery from sewage sludge, the organic matter content from this fraction can also be converted to other valuable compounds, such as carboxylates. Due to the current depletion of natural resources, used as precursors of daily products like fuels, plastics or clothing, research efforts are switching towards production of green chemicals from sewage sludge in a circular economy framework. Moreover, different technologies for the recovery of other resources from wastewater, such as nutrients, are being developed to transform WWTP into WRRF.

As a step forward from Billund Vand, Billund Biorefinery was inaugurated in 2017 in collaboration with Krüger Veolia A/S. It was established by inserting process units into the already existing facility, which enables the application of this transformation process to any other WWTP. The novelty of Billund Biorefinery revolves around the combination of new technologies in a unique way of consuming less energy for wastewater treatment while generating a water effluent far cleaner than the requirements $(25 \%$ of the maximum values). Additionally, the plant focuses on the co-digestion of sewage sludge with organic household waste and waste from restaurants, caterings, dairies or slaughterhouses. One of the main features of this plant is the use of the Exelys ${ }^{\mathrm{TM}}$ technology from Veolia, which contributes to the $50 \%$ increase in energy production in the plant, while reducing the generated sludge by $30-40 \%[107,108]$. Therefore, the sludge is easier to manage and produces an efficient organic fertilizer for agriculture. Another important feature is the ANITA $^{\mathrm{TM}}$ Mox process, also from Veolia, which reduces operational costs while removing nitrogen from the wastewater. This technology is especially suitable for treating the reject water generated during sludge dewatering, after anaerobic digestion, due to its high ammonia content [109]. At present, the generated biogas is used for the production of electricity and heat, but other uses, such as operation of fuel cells, are being considered for the future.

Following the same line, Aarhus Vand (which aims to be energy- and $\mathrm{CO}_{2}$-neutral by 2030) decided to centralize the wastewater treatment of the region, transforming two of its WWTP, Egå and Marselisborg WWTP, into energy-exporting plants [110]. They aim to generate 50\% more energy than they consume. Egå WWTP was renovated in 2016, by EnviDan A/S and Per Aarslef A/S, using cutting-edge new technologies, such as the Salsnes ${ }^{\circledR}$ filters and DEMON ${ }^{\circledR}$ [111]. With the Salnes ${ }^{\circledR}$ filters, the plant maximizes the carbon input to the anaerobic digester, replacing the conventional primary treatment [112]. Moreover, two anammox technologies are used to reduce the nitrogen load: DEMON ${ }^{\circledR}$ for the reject water from sludge dewatering and EssDe ${ }^{\circledR}$ for wastewater $[113,114]$.

Marselisborg WWTP, on the other hand, is being expanded so that it can treat 480,000 PE (from initial 200,000 PE), and become a resource recovery facility, called Marselis- 
borg ReWater, by 2028 [110]. In order to upgrade the plant, several current processes will be optimized, such as nutrient removal or the gas engines for electricity and heat production from biogas. Moreover, a nutrient recovery process will be established in order to generate struvite, as is currently performed in Aaby WWTP (which also belongs to Aarhus Vand) [115]. This technology commercializes a product called PhosphorCare ${ }^{\mathrm{TM}}$, a valuable fertilizer produced from the recovered nutrients from wastewater [116]. Additionally, Marselisborg ReWater aims to improve biogas utilization in the plant, and to use the final dewatered solids (after anaerobic digestion) as a fertilizer in agriculture $(60 \%)$ and for the cement industry (40\%) [115]. For this purpose, pellets of dried sewage sludge can be transformed to a similar material to expanded clays during a ceramization process [117].

Another Scandinavian biorefinery will be developed by Hias IKS WWTP in Norway. The Norwegian company started to rethink their WWTP in 2009, aiming to convert it to a WRRF, focusing on phosphorus removal. For that purpose, they developed the patented Hias ${ }^{\circledR}$ process, which produces struvite from wastewater (extracting about $50 \%$ of the phosphorus). The method combines two technologies: enhanced biological phosphorus removal (EBPR) and moving-bed biofilm reactor (MBBR) [118]. The process is performed in a new type of bioreactor and does not require the addition of chemicals, with a $30 \%$ lower operating cost than competing technologies [119]. During the period 2013-2015, the technology was successfully applied to a pilot plant, followed by a demonstration plant treating 10,000 PE in 2016. The next step includes the complete Hias IKS WWTP retrofit, with a capacity of 140,000 PE, by the end of 2021 [118].

\section{Conclusions}

In this paper, management of sewage sludge, together with other organic waste types in Scandinavia, was reviewed, identifying relevant organic waste sources for each country. Sewage sludge contains organic matter that can be used for energy generation or the production of green chemicals. Among the technologies applied for the stabilization of the organic matter in the sludge, anaerobic digestion is very common in WWTP, since it also recovers its energy content in the form of methane. Nevertheless, other novel routes for energy recovery from sludge are emerging, such as pyrolysis or gasification, which present a greater volume reduction. Due to the abundance of other organic wastes, anaerobic co-digestion has been used as a management strategy in Scandinavia, which, in turn, enhances the methane production. However, the use of sewage sludge for production of green chemicals has also received increased attention, due to the future depletion of natural resources.

Originally, the sole objective of WWTP was to meet the environmental policies for safe water discharge, focusing only on water recovery. This approach has changed in recent years, and different resources can be recovered from wastewater at present. In this paper, some Scandinavian examples were presented, which focus on energy and resource recovery from wastewater and sewage sludge, showing the potential of co-managing these waste streams in a circular economy framework. Therefore, future efforts will focus on the development and optimization of these strategies for sewage sludge valorization, simultaneously achieving environmental and economic sustainability.

Author Contributions: Conceptualization, C.F.-F. and C.V.; writing-original draft preparation, C.F.-F.; writing-review and editing, M.M.E., H.U. and C.V.; supervision, C.V. All authors have read and agreed to the published version of the manuscript.

Funding: This research was funded by COWI Fonden, project number A092762-001: Wastewater and Organic Waste Treatment Facilities-Net Green Energy, Nutrients and Bioproducts Producers.

Institutional Review Board Statement: Not applicable.

Informed Consent Statement: Not applicable.

Conflicts of Interest: The authors declare no conflict of interest. 


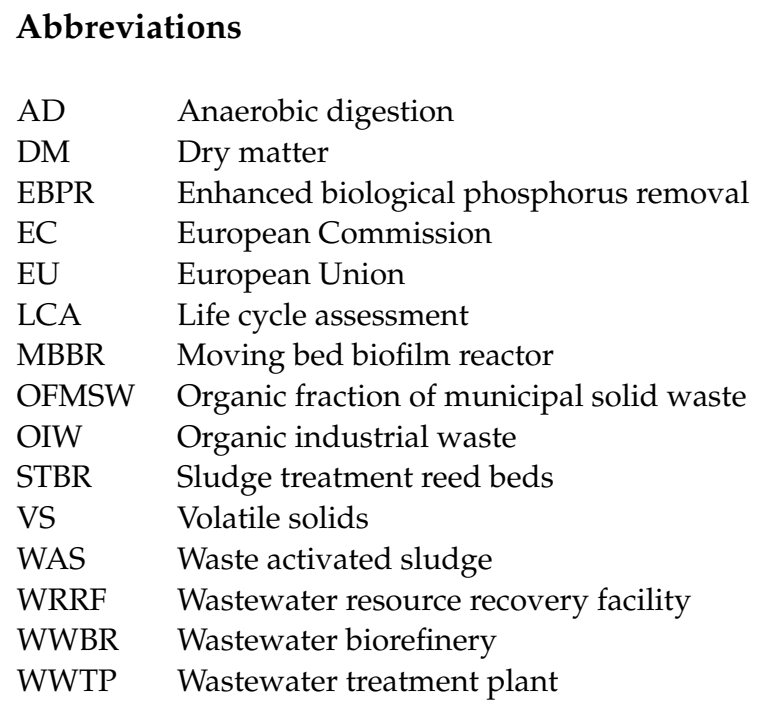

\section{References}

1. Holmgren, K.E.; Li, H.; Verstraete, W.; Cornel, P. State of the Art Compendium Report on Resource Recovery from Water; International Water Association (IWA): London, UK, 2016.

2. $\quad$ Pott, R.; Johnstone-Robertson, M.; Verster, B.; Rumjeet, S.; Nkadimeng, L.; Raper, T.; Rademeyer, S.; Harrison, S.T.L. Wastewater biorefineries: Integrating water treatment and value recovery. In The Nexus: Energy, Environment and Climate Change; Leal Filho, W., Surroop, D., Eds.; Springer: Berlin/Heidelberg, Germany, 2018; pp. 289-302; ISBN 9783319636122.

3. Peccia, J.; Westerhoff, P. We should expect more out of our sewage sludge. Environ. Sci. Technol. 2015, 49, 8271-8276. [CrossRef] [PubMed]

4. Healy, M.G.; Clarke, R.; Peyton, D.; Cummins, E.; Moynihan, E.L.; Martins, A.; Béraud, P.; Fenton, O. Resource recovery from sewage sludge. In Sewage Treatment Plants: Economic Evaluation of Innovative Technologies for Energy Efficiency; Stamatelatou, K., Tsagarakis, K.P., Eds.; IWA Publishing: London, UK, 2015; pp. 139-162; ISBN 9781780405025.

5. Bianchini, A.; Bonfiglioli, L.; Pellegrini, M.; Saccani, C. Sewage sludge management in Europe: A critical analysis of data quality. Int. J. Environ. Waste Manag. 2016, 18, 226-238. [CrossRef]

6. European Commission. Environmental, Economic and Social Impacts of the Use of Sewage Sludge on Land-Final ReportPart I: Overview Report. Available online: https:/ / ec.europa.eu/environment/archives/waste/sludge/pdf/part_i_report.pdf (accessed on 21 September 2019).

7. European Commission. Council Directive of 21 May 1991 concerning urban waste water treatment (91/271/EEC). Off. J. Eur. Commun. 1991, L135, 40-52.

8. European Commission. Council Directive of 12 June 1986 on the protection of the environment, and in particular of the soil, when sewage sludge is used in agriculture (86/278/EEC). Off. J. Eur. Commun. 1986, L181, 6-12.

9. EurEau. Europe's Water in Figures: An Overview of the European Drinking Water and Waste Water Sectors, 2017 ed.; The European Federation of National Associations of Water Services: Brussels, Belgium, 2017.

10. European Commission. Urban Waste Water Treatment Directive: Dissemination Platform. Available online: https://uwwtd.eu/ (accessed on 7 July 2020).

11. Olkiewicz, M.; Torres, C.M.; Jiménez, L.; Font, J.; Bengoa, C. Scale-up and economic analysis of biodiesel production from municipal primary sewage sludge. Bioresour. Technol. 2016, 214, 122-131. [CrossRef] [PubMed]

12. Brar, S.K.; Verma, M.; Tyagi, R.D.; Valéro, J.R.; Surampalli, R.Y. Entomotoxicity, protease and chitinase activity of Bacillus thuringiensis fermented wastewater sludge with a high solids content. Bioresour. Technol. 2009, 100, 4317-4325. [CrossRef] [PubMed]

13. Crutchik, D.; Franchi, O.; Caminos, L.; Jeison, D.; Belmonte, M.; Pedrouso, A.; Val del Rio, A.; Mosquera-Corral, A.; Campos, J. Polyhydroxyalkanoates (PHAs) production: A feasible economic option for the treatment of sewage sludge in municipal wastewater treatment plants? Water 2020, 12, 1118. [CrossRef]

14. Luo, K.; Pang, Y.; Yang, Q.; Wang, D.; Li, X.; Lei, M.; Huang, Q. A critical review of volatile fatty acids produced from waste activated sludge: Enhanced strategies and its applications. Environ. Sci. Pollut. Res. 2019, 26, 13984-13998. [CrossRef] [PubMed]

15. Xie, S.; Wickham, R.; Nghiem, L.D. Synergistic effect from anaerobic co-digestion of sewage sludge and organic wastes. Int Biodeterior. Biodegrad. 2017, 116, 191-197. [CrossRef]

16. Mehariya, S.; Patel, A.K.; Obulisamy, P.K.; Punniyakotti, E.; Wong, J.W.C. Co-digestion of food waste and sewage sludge for methane production: Current status and perspective. Bioresour. Technol. 2018, 265, 519-531. [CrossRef] [PubMed]

17. Coma, M.; Martinez-Hernandez, E.; Abeln, F.; Raikova, S.; Donnelly, J.; Arnot, T.C.; Allen, M.J.; Hong, D.D.; Chuck, C.J. Organic waste as a sustainable feedstock for platform chemicals. Faraday Discuss. 2017, 202, 175-195. [CrossRef] 
18. Sovacool, B.K. Contestation, contingency, and justice in the Nordic low-carbon energy transition. Energy Policy 2017, 102, 569-582. [CrossRef]

19. Kofoed-Wiuff, A.; Dyhr-Mikkelsen, K.; Rueskov, I.S.; Pasquali, A.; Brunak, K.; Bröckl, M.; Hagström, M. Progress towards Nordic Carbon Neutrality: Tracking Nordic Clean Energy Progress 2020; Nordic Energy Research: Oslo, Norway, 2020.

20. Banerjee, A.; Bhaskar, T.; Ghosh, D. A biorefinery approach for sewage sludge. In Waste Biorefinery: Integrating Biorefineries for Waste Valorization; Bhaskar, T., Pandey, A., Rene, E.R., Tsang, D.C.W., Eds.; Elsevier B.V.: Amsterdam, The Netherlands, 2020; pp. 393-421; ISBN 9780128182284.

21. Fytili, D.; Zabaniotou, A. Utilization of sewage sludge in EU application of old and new methods-A review. Renew. Sustain. Energy Rev. 2008, 12, 116-140. [CrossRef]

22. Cieślik, B.M.; Namieśnik, J.; Konieczka, P. Review of sewage sludge management: Standards, regulations and analytical methods. J. Clean. Prod. 2015, 90, 1-15. [CrossRef]

23. Spinosa, L.; Leschber, R.; Wichmann, K. Sewage sludge co-management: Developments in EU regulations and characterization procedures. Water Pract. Technol. 2007, 2. [CrossRef]

24. Kirchmann, H.; Börjesson, G.; Kätterer, T.; Cohen, Y. From agricultural use of sewage sludge to nutrient extraction: A soil science outlook. Ambio 2017, 46, 143-154. [CrossRef] [PubMed]

25. Shaddel, S.; Bakhtiary-Davijany, H.; Kabbe, C.; Dadgar, F.; Østerhus, S. Sustainable sewage sludge management: From current practices to emerging nutrient recovery technologies. Sustainability 2019, 11, 3435. [CrossRef]

26. Lam, K.L.; Zlatanović, L.; van der Hoek, J.P. Life cycle assessment of nutrient recycling from wastewater: A critical review. Water Res. 2020, 173, 115519. [CrossRef] [PubMed]

27. Chow, W.L.; Chong, S.; Lim, J.W.; Chan, Y.J.; Chong, M.F.; Tiong, T.J.; Chin, J.K.; Pan, G.-T. Anaerobic co-digestion of wastewater sludge: A review of potential co-substrates and operating factors for improved methane yield. Processes 2020, 8, 39. [CrossRef]

28. Sund Energy AS. Mapping Biogas in the Nordic Countries; Sund Energy AS: Oslo, Norway, 2010.

29. Nybruket, S.; Paulsrud, B.; Nedland, K.T. Erfaringer Med Hygienisering av Slam i Norge; VA-FORSK RAPPORT Nr 32; VA-Forsk: Stockholm, Sweden, 2003.

30. Mackenzie, L.D. Water and Wastewater Engineering. Design Principles and Practice; McGraw-Hill Companies, Inc.: New York, NY, USA, 2010; ISBN 978-0-07-171385-6.

31. Chang, Z.; Long, G.; Zhou, J.L.; Ma, C. Valorization of sewage sludge in the fabrication of construction and building materials: A review. Resour. Conserv. Recycl. 2020, 154, 104606. [CrossRef]

32. Baresel, C.; Lüdtke, M.; Levlin, E.; Fortkamp, U.; Ekengren, Ö. Slamavvattning i Kommunala Reningsverk—Nuläget, Begråansningar och Perspektiv (IVL Rapport B2188); IVL: Stockholm, Sweden, 2014.

33. Svenskt Vatten. Slamanvändning och Strategier för Slamanvändning (Meddelande M137); Svensk Vatten AB: Stockholm, Sweden, 2013.

34. Gao, N.; Kamran, K.; Quan, C.; Williams, P.T. Thermochemical conversion of sewage sludge: A critical review. Prog. Energy Combust. Sci. 2020, 79, 100843. [CrossRef]

35. Chen, P.; Xie, Q.; Addy, M.; Zhou, W.; Liu, Y.; Wang, Y.; Cheng, Y.; Li, K.; Ruan, R. Utilization of municipal solid and liquid wastes for bioenergy and bioproducts production. Bioresour. Technol. 2016, 215, 163-172. [CrossRef] [PubMed]

36. Kehrein, P.; van Loosdrecht, M.; Osseweijer, P.; Garfí, M.; Dewulf, J.; Posada, J. A critical review of resource recovery from municipal wastewater treatment plants-Market supply potentials, technologies and bottlenecks. Environ. Sci. Water Res. Technol. 2020, 6, 877-910. [CrossRef]

37. Callegari, A.; Capodaglio, A.G. Properties and beneficial uses of (bio)chars, with special attention to products from sewage sludge pyrolysis. Resources 2018, 7, 20. [CrossRef]

38. Ali, A.M.; Nesse, A.S.; Eich-Greatorex, S.; Sogn, T.A.; Aanrud, S.G.; Aasen Bunæs, J.A.; Lyche, J.L.; Kallenborn, R. Organic contaminants of emerging concern in Norwegian digestates from biogas production. Environ. Sci. Process. Impacts 2019, 21, 1498-1508. [CrossRef] [PubMed]

39. Keller, A.S.; Jimenez-Martinez, J.; Mitrano, D.M. Transport of nano- and microplastic through unsaturated porous media from sewage sludge application. Environ. Sci. Technol. 2020, 54, 911-920. [CrossRef] [PubMed]

40. Eggen, T.; Heimstad, E.S.; Nikiforov, V.; Vogelsang, C. Maximum Limit Values for Selected Hazardous Organic Contaminants (HOCs) in Secondary Raw Materials Used in Fertilisers and Soil Products (NIBIO Rapport 5/110/2019); Norsk Institut for Bioøkonomi (NIBIO): Ås, Norway, 2019.

41. Díaz-Cruz, M.S.; García-Galán, M.J.; Guerra, P.; Jelic, A.; Postigo, C.; Eljarrat, E.; Farré, M.; López de Alda, M.J.; Petrovic, M.; Barceló, D. Analysis of selected emerging contaminants in sewage sludge. Trends Anal. Chem. 2009, 28, 1263-1275. [CrossRef]

42. Papineschi, J.; Hoog, D.; Chowdhury, T.; Durrant, C.; Thomson, A. Analysis of Nordic Regulatory Framezork and Its Effect on Waste Prevention and Recycling in the Region (2019:522); Nordic Council of Ministers, Ed.; Nordic Council of Ministers/Publication Unit: Copenhagen, Denmark, 2019; ISBN 9789289361033.

43. Dansk Vand- og Spildevandsforening (DANVA). Water in Figures 2019, DANVA Statistics \& Benchmarking. Available online: https:/ / www.danva.dk/media/6355/2019_water-in-figures_web.pdf (accessed on 28 July 2020).

44. Dansk Vand- og Spildevandsforening (DANVA). Water in Figures 2020, DANVA Statistics \& Benchmarking. Available online: https://www.danva.dk/media/7251/2020_water-in-figures_web.pdf (accessed on 21 April 2021).

45. Nielsen, S.; Larsen, J.D. Operational strategy, economic and environmental performance of sludge treatment reed bed systemsBased on 28 years of experience. Water Sci. Technol. 2016, 74, 1793-1799. [CrossRef] [PubMed] 
46. Brix, H. Sludge dewatering and mineralization in sludge treatment reed beds. Water 2017, 9, 160. [CrossRef]

47. Nielsen, S.; Bruun, E.W. Sludge quality after 10-20 years of treatment in reed bed systems. Environ. Sci. Pollut. Res. 2015, 22, 12885-12891. [CrossRef] [PubMed]

48. Statistisk Sentralbyrå Norway (SSB). Land Use and Land Cover. Available online: https://www.ssb.no/en/natur-og-miljo/ statistikker/arealstat (accessed on 10 May 2021).

49. Berge, G.; Chaudhary, M. Kommunale Avløp 2017. Ressursinnsats, Utslipp, Rensing og Slamdisponering 2017. Gebyrer 2018 (Rapporter 2018/40); Statistisk Sentralbyrå: Oslo, Norway, 2018; ISBN 9788253798523.

50. Paruch, A.M.; Mæhlum, T.; Obarska-Pempkowiak, H.; Gajewska, M.; Wojciechowska, E.; Ostojski, A. Rural domestic wastewater treatment in Norway and Poland: Experiences, cooperation and concepts on the improvement of constructed wetland technology. Water Sci. Technol. 2011, 63, 776-781. [CrossRef] [PubMed]

51. Ødegaard, H.; Rusten, B.; Storhaug, R.; Paulsrud, B. Veiledning for Dimensjonering av Avløpsrenseanlegg (Rapportnr: 168/2009); Norsk Vann: Hamar, Norway, 2009.

52. Norsk Institutt for Bioøkonomi (NIBIO). Available online: https:/ / www.nibio.no/ (accessed on 30 July 2020).

53. Landbruks- og matdepartementet. Forskrift om Gjødselvarer mv. av Organisk Opphav. 2003. Available online: https://lovdata. no/dokument/SF/ forskrift/2003-07-04-951 (accessed on 30 July 2020).

54. Landbruks- og matdepartementet. Forskrift om Endring i Forskrift om Gjødselvarer mv. av Organisk Opphav (Avløpsslambasert Gjødsel Med Særskilte Bruksvilkår). 2019. Available online: https://lovdata.no/dokument/LTI/forskrift/2019-01-30-58 (accessed on 30 July 2020).

55. Statistics Sweden (SCB). Production and Use of Sewage Sludge from Municipal Waste Water Treatment Plants by County and Use Category. Every Other Year 2014-2018. Available online: http:/ /www.statistikdatabasen.scb.se/pxweb/en/ssd/START_ _MI_MI0106/MI0106T03/ (accessed on 16 September 2020).

56. Åkerblom, A.; Lüdtke, M.; Lans, N.; Linderholm, L.; Johansson, E.; Unger, M.L.; Gunnarsson, Å.; Dimberg, A.; Åkerblom, S. Wastewater Treatment in Sweden 2018; Swedish Environmental Protection Agency: Stockholm, Sweden, 2020; ISBN 978-91-620-8867-5.

57. Jarvis, A. Biogas ur Gödsel, Avfall och Restprodukter-Goda Svenska Exempel; Swedish Environmental Protection Agency: Stockholm, Sweden, 2012; ISBN 9789162065188.

58. Valderrama, C.; Granados, R.; Cortina, J.L. Stabilisation of dewatered domestic sewage sludge by lime addition as raw material for the cement industry: Understanding process and reactor performance. Chem. Eng. J. 2013, 232, 458-467. [CrossRef]

59. Ekane, N.; Barquet, K.; Rosemarin, A. Resources and risks: Perceptions on the application of sewage sludge on agricultural land in Sweden, a case study. Front. Sustain. Food Syst. 2021, 5, 647780. [CrossRef]

60. Miljö- och energidepartementet. Kommittédirektiv. Giftfri och Cirkulär Återföring av Fosfor Från Avloppsslam (Dir. 2018:67; Stockholm, 2018. Available online: https:/ / www.regeringen.se/rattsliga-dokument/kommittedirektiv /2018/07/dir.-201867/ (accessed on 19 August 2020).

61. European Commission. European Commission Urban Waste Water Website: Denmark. Graphs for National Stats. Available online: https: / / uwwtd.eu/Denmark/stats/graphs (accessed on 7 July 2020).

62. Statistisk Sentralbyrå Norway (SSB). Discharges and treatment of municipal waste water 05279: Disposal of sewage slugde (C) 2002-2018. Available online: https:/ / www.ssb.no/en/statbank/table/05279 (accessed on 16 September 2020).

63. Statistics Denmark. Waste Generation by Industry, Kind of Treatment and Waste Category. Available online: https://www.

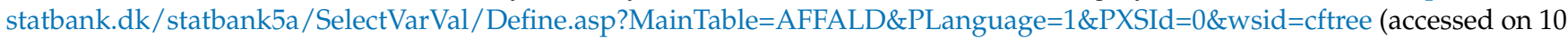
May 2021).

64. DAKOFA. Waste and Resources Network Denmark Incineration in Denmark. Available online: https:// dakofa.com/element/ incineration-in-denmark/ (accessed on 10 May 2021).

65. Frijns, J.; Hofman, J.; Nederlof, M. The potential of (waste)water as energy carrier. Energy Convers. Manag. 2013, 65, 357-363. [CrossRef]

66. European Commission. Directive 2008/98/EC of the European Parliament and of the Council of 19 November 2008 on waste and repealing certain Directives (Text with EEA relevance). Off. J. Eur. Union 2008, L312, 3-30.

67. European Commission. Council Directive 1999/31/EC of 26 April 1999 on the landfill of waste. Off. J. Eur. Communities 1999, L182. [CrossRef]

68. Thomsen, M. Wastewater Treatment and Discharge; Scientific Report from DCE-Danish Centre for Environment and Energy (no. 193); Aarhus University, DCE—Danish Centre for Environment and Energy: Aarhus, Denmark, 2016.

69. BIOFOS. Miljøberetning 2019. 2019. Available online: https://biofos.dk/wwwroot/media/1430/publiceret-miljoeberetning_20 19-d20-354027-10.pdf (accessed on 19 August 2020).

70. Danish Ministry of Environment and Food. Bekendtgørelse om anvendelse af affald til jordbrugsformål. In Miljø- og Fødevaremin., j. nr. 2018-6950; Danish Ministry of Environment and Food: Copenhagen, Denmark, 2018.

71. Statistisk Sentralbyrå Norway (SSB). Discharges and Treatment of Municipal Waste Water 05314: Heavy Metals in Sewage Sludge (mg/kg Dry Weight) 1993-2019. Available online: https://www.ssb.no/en/statbank/table/05314/ (accessed on 16 September 2020).

72. Werther, I.L.; Petersen, P.H. Nabotjek af Reglerne om Spildevandsslam: Sverige, Norge, Finland, Tyskland og England (Miljoprojekt nr. 1989); Miljøstyrelsen: København, Denmark, 2018; ISBN 9788793614833. 
73. Statistics Sweden (SCB). Concentrations of Nutrients, Metals and Organic Indicator Substances in Sludge from Municipal Wastewater Treatment Plants. Every Other Year 2014-2018. Available online: http:/ /www.statistikdatabasen.scb.se/pxweb/en/ ssd/START_MI_MI0106/MI0106T05/ (accessed on 7 July 2020).

74. European Commission. Regulation (EU) 2019/1009 of the European Parliament and of the Council of 5 June 2019 laying down rules on the making available on the market of EU fertilising products and amending Regulation (EC) No 1069/2009 and (EC) No 1107/2009 and repealing Regulation (EC) No 2003/2003 (Text with EEA relevance). Off. J. Eur. Union 2019, L170, 1-114.

75. EasyMining Ash2Phos. Available online: https://www.easymining.se/technologies/ash2phos (accessed on 11 May 2021).

76. European Commission. Communication from the Commission to the European Parliament, the Council, the European Economic and Social Committee and the Committee of the Regions, Towards a Circular Economy: A zero waste programme for Europe 2014. Available online: https:/ / eur-lex.europa.eu/legal-content/EN/TXT/?uri=celex\%3A52014DC0398 (accessed on 17 December 2020).

77. European Commission. Communication from the Commission to the European Parliament, the Council, the European Economic and Social Committee and the Committee of the Regions, Closing the loop-An EU action plan for the Circular Economy 2015. Available online: https:/ / eur-lex.europa.eu/legal-content/EN/TXT/?uri=CELEX\%3A52015DC0614 (accessed on 18 December 2020).

78. Yoshida, H.; Christensen, T.H.; Scheutz, C. Life cycle assessment of sewage sludge management: A review. Waste Manag. Res. J. A Sustain. Circ. Econ. 2013, 31, 1083-1101. [CrossRef] [PubMed]

79. Cao, Y.; Pawłowski, A. Life cycle assessment of two emerging sewage sludge-to-energy systems: Evaluating energy and greenhouse gas emissions implications. Bioresour. Technol. 2013, 127, 81-91. [CrossRef]

80. Samolada, M.C.; Zabaniotou, A.A. Comparative assessment of municipal sewage sludge incineration, gasification and pyrolysis for a sustainable sludge-to-energy management in Greece. Waste Manag. 2014, 34, 411-420. [CrossRef]

81. Gentil, E.C.; Damgaard, A.; Hauschild, M.; Finnveden, G.; Eriksson, O.; Thorneloe, S.; Kaplan, P.O.; Barlaz, M.; Muller, O.; Matsui, Y.; et al. Models for waste life cycle assessment: Review of technical assumptions. Waste Manag. 2010, 30, 2636-2648. [CrossRef]

82. European Commission. Directive (EU) 2018/851 of the European Parliament and of the Council of 30 May 2018 amending Directive 2008/98/EC on waste (Text with EEA relevance). Off. J. Eur. Union 2018, L150, 109-140.

83. European Commission. Communication from the Commission to the Council and the European Parliament on Future Steps in Bio-Waste Management in the European Union (COM(2010)235 Final). Available online: https:/ / eur-lex.europa.eu/legalcontent/EN/TXT/?uri=CELEX\%3A52010DC0235 (accessed on 21 September 2019).

84. European Environment Agency. Bio-Waste in Europe-Turning Challenges into Opportunities (EEA Report No 04/2020); Publications Office of the European Union: Luxembourg, 2020; ISBN 9789294802231.

85. European Commission. Proposal for a Directive of the European Parliament and of the Council Amending Directives 2008/98/EC on Waste, 94/62/EC on Packaging and Packaging Waste, 1999/31/EC on the Landfill of Waste, 2000/53/EC on End-of-Life Vehicles, 2006/66/EC on Batteries and Accumulators and Waste Batteries and Accumulators, and 2012/19/EU on Waste Electrical and Electronic Equipment (Text with EEA Relevance). Available online: https://eur-lex.europa.eu/legal-content/DA/ALL/ ?uri=CELEX:52014SC0209 (accessed on 27 July 2020).

86. European Commission. Directive (EU) 2018/850 of the European Parliament and of the Council of 30 May 2018 amending Directive 1999/31/EC on the landfill of waste (Text with EEA relevance). Off. J. Eur. Union 2018, L150, 100-108.

87. Madsen, M.L.; Kiilerich, O.; Nissen, A.L.; Nissen, E.L. Affaldsstatistik 2018 (Miljøprojekt nr. 2133); Miljøstyrelsen: København, Denmark, 2020; ISBN 9788770381833.

88. Miljøstyrelsen. Denmark without Waste: Recycle More-Incinerate Less; Miljøstyrelsen: København, Denmark, 2013.

89. Damgaard, C.K.; Christensen, C.; Werther, I.; Christensen, L.H.; Nyegaard, R. Organisk Affald fra Servicesektoren: Samfundsøkonomisk Vurdering af Øget Genanvendelse (Miljøprojekt nr. 2070); Miljøstyrelsen: København, Denmark, 2019; ISBN 9788770380454.

90. Foged, H.L. Livestock Manure to Energy: Status, Technologies and Innovation in Denmark; Agro Business Park: Tjele, Denmark, 2012.

91. Statistisk Sentralbyrå Norway (SSB). Waste from Households-Household Waste by Material. Available online: https: / www. ssb.no/en/natur-og-miljo/statistikker/avfkomm (accessed on 16 September 2020).

92. Norwegian Directorate of Fisheries Aquaculture Statistics: Total Sale 1998-2019. Available online: https://www.fiskeridir.no/ English/Aquaculture/Statistics/Total (accessed on 3 August 2020).

93. Torrissen, O.; Hansen, P.K.; Aure, J.; Husa, V.; Andersen, S.; Strohmeier, T.; Olsen, R.E. Næringsutslipp fra Havbruk—Nasjonale og Regionale Perspektiv. (Rapport fra Havforskningen nr 21-2016); Havforskningsinstituttet: Bergen, Norway, 2016.

94. Bjørndal, T.; Holte, E.A.; Hilmarsen, Ø.; Tusvik, A. Analyse av Lukka Oppdrett av Laks—Landbaseret og i sjø: Produksjon, Økonomi og Risiko (Sluttrapport FHF Prosjekt 901442); The Norwegian Seafood Research Fund (FHF): Oslo, Norway, 2018.

95. Estevez, M.M.; Sapci, Z.; Linjordet, R.; Morken, J. Incorporation of fish by-product into the semi-continuous anaerobic co-digestion of pre-treated lignocellulose and cow manure, with recovery of digestate's nutrients. Renew. Energy 2014, 66, 550-558. [CrossRef]

96. Avfall Sverige. Svensk Avfallshantering 2019; Avfall Sverige: Malmö, Sweden, 2020.

97. BIOGÖDSEL. Certifierad Återvinning av Biogödsel. Available online: https://www.biogodsel.se/certifiering/ (accessed on 8 July 2020).

98. Mata-Alvarez, J.; Dosta, J.; Macé, S.; Astals, S. Codigestion of solid wastes: A review of its uses and perspectives including modeling. Crit. Rev. Biotechnol. 2011, 31, 99-111. [CrossRef] [PubMed]

99. Avfall Norge. Status Biologisk Behandling 2019; Avfall Norge: Oslo, Norway, 2019.

100. Wittrup, S. Billund Vand har lavet biogas af madaffald i 15 år. Ingeniøren. 2012. Available online: https://ing.dk/artikel/billundvand-har-lavet-biogas-af-madaffald-i-15-ar-127927 (accessed on 8 September 2019). 
101. IVAR. Kort om IVAR. Available online: https:/ / www.ivar.no/Omivar/ (accessed on 28 November 2019).

102. Estevez, M.M.; Tomczak-wandzel, R.; Akervold, K.; Tornes, O. Co-digestion of waste from the salmon aquaculture sector with regional sewage sludge: Effects on methane yield and digestate nutrient content. Eco-Energetics Technol. Environ. Law Econ. 2019, 2, 29-34. [CrossRef]

103. IVAR. Minorga Gjødselfabrikk. Available online: https://www.ivar.no/minorga/ (accessed on 28 November 2019).

104. Nunes, J.; Lindqvist, P.; Tumlin, S.; Neth, M.; Lumley, D. Teknisk Beskrivning: Tillståndsansökan för Ryaverket; Gryaab AB: Göteborg, Sweden, 2017.

105. Gryaab. Kort om Gryaab. Available online: https://www.gryaab.se/vad-vi-gor/kort-om-gryaab/ (accessed on 8 September 2019).

106. SVENSKT VATTEN. Aktivt Uppströmsarbete Med Revaq-Certifiering. Available online: https://www.svensktvatten.se/ vattentjanster/avlopp-och-miljo/kretslopp-och-uppstromsarbete/revaq-certifiering/ (accessed on 8 September 2019).

107. VEOLIA. Exelys ${ }^{\mathrm{TM}}$ Continuous Thermal Hydrolysis. Available online: https://www.veoliawatertechnologies.com/en/products/ exelys (accessed on 8 September 2019).

108. Billund Vand \& Energi. Et Fyrtårnsprojekt for Miljø og Eksport. Available online: https://www.billundvand.dk/b $\backslash T 1$ \aeredygtighed/billund-biorefinery/ (accessed on 11 May 2021).

109. VEOLIA. ANITA ${ }^{\mathrm{TM}}$ Mox: The MBBR Solution for High Ammonia Waste. Available online: https://www.veoliawatertechnologies. com/en/technologies/anita-mox (accessed on 11 May 2021).

110. Aarhus Vand. Aarhus ReWater-På Vej Mod Verdens Mest Effektive Ressourceanlæg. Available online: https:/ / www.aarhusvand. $\mathrm{dk} /$ projekter/vores-losninger/aarhus-rewater/ (accessed on 11 May 2021).

111. EnviDan. The Wastewater Treatment Plant of the Future Is Located in Egå. Available online: https://www.envidan.com/cases/ expansion-of-egaa-wwtp (accessed on 11 May 2021).

112. Salsnes Filter. Municipal Wastewater Treatment Applications. Available online: https://www.salsnes-filter.com/applications/ municipal/ (accessed on 11 May 2021).

113. World Water Works. DEMON®Anammox Treatment Technology. Available online: https://www.worldwaterworks.com/ technologies/demon (accessed on 11 May 2021).

114. EssDe. EssDe®in the Mainstream Plant. Available online: https://www.essde.com/en/essde/self-sufficient-wastewatertreatment-plant (accessed on 11 May 2021).

115. Møller, F.B. The Energy Positive WWTP. Wastewater as a Major Challenge and a Great Opportunity. 2020. Available online: https:/ / marmara.gov.tr/wp-content/uploads/2020/12/Flemming-B.-Moller.pdf (accessed on 15 May 2021).

116. Aarhus Vand International. From Wastewater to Valuable Fertiliser. Available online: https://www.aarhusvand.dk/en/ international/solutions / from-wastewater-to-valuable-fertiliser2/ (accessed on 11 May 2021).

117. Cusidó, J.A.; Soriano, C. Valorization of pellets from municipal WWTP sludge in lightweight clay ceramics. Waste Manag. 2011, 31, 1372-1380. [CrossRef] [PubMed]

118. Hias. The Hias®Process. Available online: https:/ /www.hias.as / (accessed on 11 May 2021).

119. Olsen, T. Utvinner Fosfor fra Avløpsvann. Available online: https://www.vanytt.no/2017/12/27/utvinner-fosfor-fraavlopsvann/ (accessed on 11 May 2021). 